\title{
Sources of dissolved organic matter during storm and inter-storm conditions in a lowland headwater catchment: constraints from high-frequency molecular data
}

\author{
L. Jeanneau ${ }^{1}$, M. Denis ${ }^{1}$, A.-C. Pierson-Wickmann ${ }^{1}$, G. Gruau ${ }^{1}$, T. Lambert ${ }^{1, \mathrm{a}}$, and P. Petitjean ${ }^{1}$ \\ ${ }^{1}$ Géosciences Rennes UMR 6118, Université de Rennes 1/CNRS, 35042 Rennes, France \\ anow at: University of Liège, Institut de Physique (B5), 4000 Sart Tilman, Belgium
}

Correspondence to: L. Jeanneau (laurent.jeanneau@univ-rennes1.fr)

Received: 12 January 2015 - Published in Biogeosciences Discuss.: 20 February 2015

Revised: 19 June 2015 - Accepted: 02 July 2015 - Published: 24 July 2015

\begin{abstract}
The transfer of dissolved organic matter (DOM) at soil-river interfaces controls the biogeochemistry of micropollutants and the equilibrium between continental and oceanic $\mathrm{C}$ reservoirs. Understanding the mechanisms controlling this transfer is fundamental to ecology and geochemistry. DOM delivery to streams during storms is assumed to come from the flushing of preexisting soil DOM reservoirs mobilized by the modification of water flow paths. We tested this hypothesis by investigating the evolution of the composition of stream DOM during inter-storm conditions and five storm events monitored with high-frequency sampling. The composition of DOM was analyzed using thermally assisted hydrolysis and methylation (THM) with tetramethylammonium hydroxide (TMAH) coupled to a gas chromatograph and mass spectrometer. In inter-storm conditions, stream DOM is derived from the flushing of soil DOM, while during storm events, the modification of the distribution of chemical biomarkers allows the identification of three additional mechanisms. The first one corresponds to the destabilization of microbial biofilms due to the increase in water velocity, resulting in the fleeting export of a microbial pool. The second mechanism corresponds to the erosion of soils and river banks, leading to a partition of organic matter between particulate and dissolved phases. The third mechanism is linked to the increase in water velocity in soils that could induce the erosion of macropore walls, leading to an in-soil partition between soil microparticles and dissolved phase. The contribution of this in-soil erosive process would be linked to the magnitude of the hydraulic gradient following the rise of the water table and could persist after the recession, which could
\end{abstract}

explain why the return to inter-storm composition of DOM does not follow the same temporal scheme as the discharge. These results are the most important factors in understanding the transfer of nutrients and micropollutants at the soil-river interfaces during the hot moments that are storm events.

\section{Introduction}

The transfer of dissolved organic matter (DOM) across soilriver interfaces is a globally relevant carbon flux (Cole et al., 2007) and a major control on the biogeochemistry of micropollutants (Corapcioglu and Jiang, 1993; Raymond et al., 2013). While the mechanisms governing this transfer have clear ecological, societal and geochemical implications, key unknowns persist concerning the production and transfer of DOM across terrestrial-aquatic interfaces (Kicklighter et al., 2013; Lambert et al., 2014). Understanding DOM dynamics in headwater catchments is particularly important because over $90 \%$ of stream length occurs in small catchments (Bishop et al., 2008) and DOM yield per square meter is highest in headwaters (Agren et al., 2007), resulting in a large proportion of river DOM ultimately coming from headwater catchment soils (Billett et al., 2006; Morel et al., 2009). Organic matter sources are typically abundant in headwater catchment soil, meaning that DOM flux depends primarily on water flow path (McDonnell, 2003; Morel et al., 2009), which changes on seasonal and event scales in response to hydroclimatic conditions (Hinton et al., 1998). Because storm events connect a larger portion of the land- 
scape with surface waters, more than $60 \%$ of annual dissolved organic carbon (DOC; the parameter commonly used to quantify DOM concentration) load can occur during storm events (Morel et al., 2009). DOC concentration typically increases during storm events as elevated water table and enhanced near-surface flow cause the leaching of DOM-rich soil horizons (Maurice et al., 2002; McGlynn and McDonnell, 2003).

The shift in flow paths during storm events can also cause changes in DOM composition and biodegradability (McLaughlin and Kaplan, 2013). Low-frequency spectroscopic measurements of UV absorbance and fluorescence suggested that DOM aromaticity increases during storm events, potentially due to the mobilization of aromatic DOM from surface soil horizons (Hood et al., 2006; Maurice et al., 2002). However, high-frequency spectroscopic measurements have shown that concentration and composition are not always linked and that compositional differences in DOM can persist long after concentration returns to pre-event levels (Austnes et al., 2010; Knorr, 2013; Saraceno et al., 2009; Yang et al., 2013). This shift in DOM signature has been attributed to the in-stream production of fluorescing DOM (Austnes et al., 2010) or sustained hydrologic contribution from surface soil horizons after the return to low-flow conditions (Strohmeier et al., 2013).

Analysis of the molecular composition of DOM during low- and high-flow conditions is considerably less common than spectroscopic data due to analytical cost and complexity. However, low-frequency lignin phenol data indicate that less degraded lignins are mobilized during storm events potentially due to the mobilization of particles by erosion combined with the separation of the lignin compounds into the solid and dissolved phase (Dalzell et al., 2005; Hernes et al., 2008). This partitioning process could be linked to in-stream production of fluorescing DOM (Austnes et al., 2010). However, because molecular data are typically collected using low-frequency water sampling strategies (one sample per storm event), it is not possible to evaluate the persistence of shifts in DOM aromatic fingerprint after storm events.

These asymmetrical shifts in DOM composition during and after storm events suggest that in addition to changing flow path and DOM transport, storm events alter mechanisms of DOM production or processing. To test this hypothesis, we collected high-frequency molecular data during five successive storm events, and we compared them with background information on the molecular composition of soil organic matter (SOM), soil DOM and inter-storm river DOM in a lowland headwater catchment in Brittany, France.

Among the different techniques available to study the molecular composition of DOM, thermally assisted hydrolysis and methylation (THM) using tetramethylammonium hydroxide (TMAH) coupled to a gas chromatograph and mass spectrometer (THM-GC-MS) seems to be particularly suitable. This technique can be used to simultaneously analyze phenol markers from lignins and tannins (LIG-TAN), carbohydrates (CAR), and fatty acids (FA) (Grasset et al., 2009). LIG-TAN are commonly used to monitor the input of terrestrially derived organic matter to oceans (Hedges and Parker, 1976), and their investigation has led to the partitioning process invoked for lignin compounds during storm events (Dalzell et al., 2005; Hernes et al., 2008). Analysis of CAR can differentiate between plant-derived and microbial inputs (Rumpel and Dignac, 2006) since the distribution of noncellulosic monosaccharides is dominated by pentose (C5) for plant-derived inputs and by hexose (C6) and deoxyhexose (deoxyC6) for microbial inputs. Similar to CAR, the distribution of FA differs in plant-derived and microbial inputs (Cranwell, 1974; Eglinton and Hamilton, 1967; Lucas García et al., 2001; Matsuda and Koyama, 1977). The combination of these markers allows the investigation of the balance between microbial and plant-derived markers differentiating between soil DOM from organic-rich horizons, characterized by a high proportion of plant-derived markers, and organic-poor horizons, characterized by a high proportion of microbial markers, in a wetland subject to fluctuating watertable levels (Jeanneau et al., 2014).

Two main questions motivated our work. First, how does the molecular composition of DOM vary during and between storm events? Second, what new insights can molecular data provide on the sources and transfer mechanisms of DOM during storms?

\section{Materials and methods}

\subsection{Site description}

We collected samples from the outlet of the Kervidy-Naizin catchment, a $4.9 \mathrm{~km}^{2}$ lowland catchment located in central Brittany in western France (Fig. 1). The catchment is a part of a long-term monitoring research program aimed at understanding the impact of agricultural intensification and climate change on hydrologic processes and water quality. Numerous hydrological and biogeochemical studies have already been undertaken at this site (Lambert et al., 2013, and references therein), including investigating the effect of storm events on hydrology (Aubert et al., 2013; Durand and Juan Torres, 1996; Morel et al., 2009) and DOM sources and transfer processes (Lambert et al., 2011, 2013, 2014; Morel et al., 2009).

The Kervidy-Naizin catchment has a temperate oceanic climate with a mean annual temperature and precipitation (1993-2011) of $10.7^{\circ} \mathrm{C}$ and $814 \mathrm{~mm}$, respectively. Rainfall events rarely exceed $20 \mathrm{~mm} \mathrm{day}^{-1}$, and $80 \%$ of rainfall events have an intensity of less than $4 \mathrm{~mm} \mathrm{~h}^{-1}$. The stream is ephemeral and often does not flow from the end of $\mathrm{Au}-$ gust to October due to the small volume of water stored in the bedrock. High flow generally lasts from December to April, with maximum discharges in February and March. The catchment topography is gentle, with hillslope gradi- 
ents of less than $5 \%$ and elevation ranging from 93 to $135 \mathrm{~m}$ above sea level. Soil depth ranges from 0.5 to $1.5 \mathrm{~m}$, with soils classified as silty loams, specifically Stagnic Fluvisols (IUSS Working Group WRB, 2006) developed from alluvial material and Brioverian schist. The aquifer in the catchment consists of unconsolidated weathered bedrock, underlain by a locally fractured but generally impermeable unmodified bedrock.

The hydrologic regime is characterized by three distinct periods (Lambert et al., 2013; Molenat et al., 2008). First, in the autumn, the water table reaches the riparian zone but remains below the surface in the upland domain (period A). Second, as precipitation increases through the winter, the water table rises in the upland domain, connecting upland and riparian areas hydrologically and consequently increasing upland groundwater flow towards the riparian zone (period B). Third, in late spring and summer, upland groundwater flow decreases progressively, resulting in a gradual airdrying of wetland soils (period C).

The extent of interaction between the organic-rich soils and groundwater fluctuates strongly with hydroclimatic conditions within and between years. During dry hydrologic years, it may be restricted to riparian or wetland areas, which represent less than $5 \%$ of the total catchment area. Conversely, during wet hydrological years, the water table may be in contact with $20 \%$ of the total catchment surface area (Crave and Gascuel-Odoux, 1997).

\subsection{Previous data}

\subsubsection{Molecular data on SOM and soil DOM}

The molecular composition of SOM and the spatiotemporal variation in the molecular composition of soil DOM were investigated in the central, most widespread wetland zone of the catchment (the so-called Mercy Wetland) during the hydrologic year 2010-2011 (Jeanneau et al., 2014). Concerning SOM, the proportion of LIG-TAN, CAR and FA were 16,29 and $55 \%$, respectively, in the organomineral horizon and 4,3 and $93 \%$, respectively, in the mineral horizon. The deoxyC6 / C5 ratio was 0.4 and 0.2 in the organomineral and mineral horizons, respectively and the proportion of plantderived markers was 88 and $71 \%$ in the organomineral and mineral horizons, respectively.

During hydrologic period B, when the five studied storm events were sampled, there was a clear differentiation between surface $(10 \mathrm{~cm})$ and deep $(50 \mathrm{~cm})$ soil DOM. In the surface horizons, the proportion of plant-derived markers remained higher than $70 \%$, with a mean value of $0.8 \pm 0.1$ (standard deviation) for the deoxyC6 / C5 ratio, while in the deep horizon, this proportion was lower than $30 \%$, with a mean value of $1.3 \pm 0.2$ (standard deviation) for the deoxyC6 / C5 ratio.

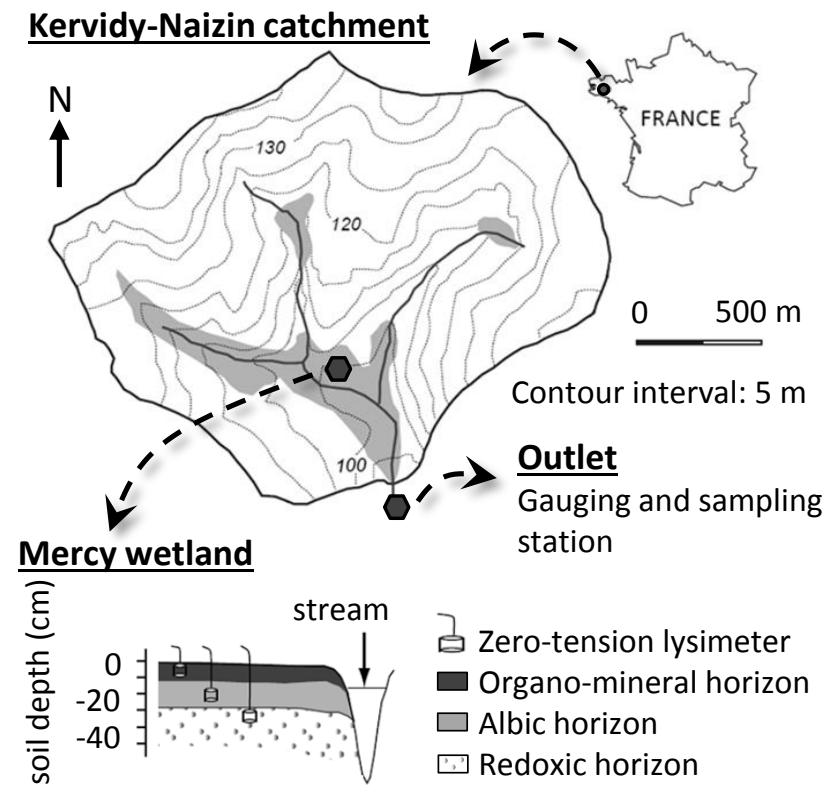

Figure 1. Map of the Kervidy-Naizin critical zone observatory (Brittany, France). Grey areas located along the channel network indicate the maximum extent of the wetland zones. Coordinates of the outlet are $48.0057 \mathrm{~N}, 2.8313 \mathrm{E}$ (decimal degrees).

\subsubsection{Previous data on river samples}

The $\delta^{13} \mathrm{C}$ values during storm events ranged between the values recorded in the soil solution of the organic-rich surface horizon at the beginning of storm events and those of the organic-poor deep horizon at the end of storm events. We separated the storm-flow hydrograph into three successive components: (i) overland flow above the saturated wetland soil horizons; (ii) subsurface flow through the uppermost organic-rich horizon of wetland soils; and (iii) subsurface return flow from shallow hillslope groundwater passing through deeper organic-poor soil horizons in wetlands (Lambert et al., 2011, 2014). These patterns supported the hypothesis that a portion of DOM flux during storm is generated by the mobilization of preexisting DOM pools during water table rise.

\subsection{Sampling}

Soils from the Mercy Wetland were sampled with a hand auger in October 2010. Three sample subsets were collected in the organomineral $(0-10 \mathrm{~cm})$ and the mineral $(30-40 \mathrm{~cm})$ horizons. After the removal of roots and gravels by hand, all samples were freeze-dried and crushed using an agate mortar.

Five storm events were sampled between 4 December 2010 and 19 February 2011, during hydrological period $\mathrm{B}$, when wetland soils are most hydrologically connected to stream flow (Fig. 2). The numbering of storm events follows Lambert et al. (2014). Events 2, 3, 4, 5 and 6 were sam- 


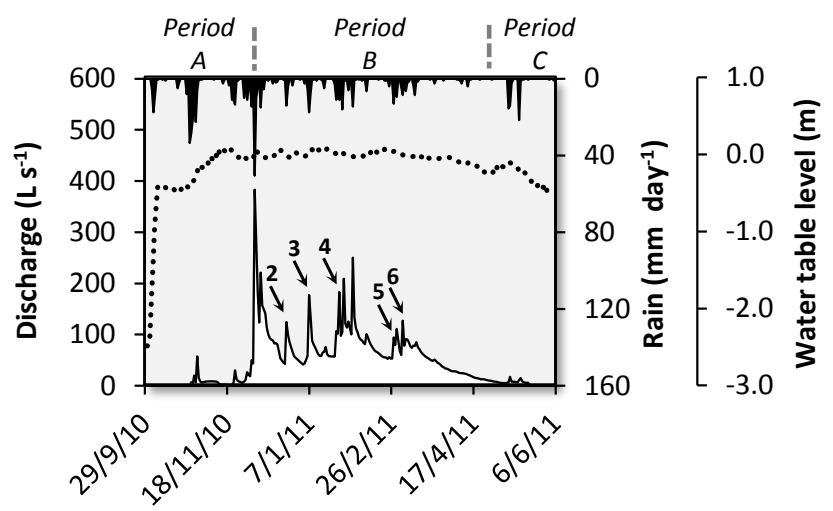

Figure 2. Discharge (white area), daily rainfall (black area) and water table level in the wetland domain (dashed line) during the hydrologic year 2010-2011. Sampled storm events are indicated by numbers and arrows. Dates are given in day/month/year.

pled on 04 December, 19 December, 06 January, 13 February and 19 February, respectively. An automatic gauge station at the outlet of the catchment recorded stream discharge every minute. The beginning of a flood was determined by an increase in the stream discharge of $>1 \mathrm{~L} \mathrm{~s}^{-1}$ over $10 \mathrm{~min}$. Turbidity was monitored by an APC-TU Ponselle every 30 seconds, with $10 \mathrm{~min}$ averages recorded. Cumulative rainfall was recorded every hour at a weather station located ca. $300 \mathrm{~m}$ from the catchment outlet. An automatic sampler (Sigma 900 Max) collected $1 \mathrm{~L}$ stream water during storms; the samples were stored at $4{ }^{\circ} \mathrm{C}$ in polypropylene (PP) bottles in a shed at the outlet of the catchment (Fig. 1). Sampling frequency during storm events varied from one sample every $30 \mathrm{~min}$ to one sample every hour, depending on the hydrograph variations. During baseflow conditions between storms, we collected manual samples daily (5 p.m.) in $60 \mathrm{~mL}$ PP bottles for DOC monitoring and every 2 weeks in $1 \mathrm{~L}$ glass bottles for isotopic and molecular analyses. Stream water was filtered at $0.22 \mu \mathrm{m}$ using cellulose acetate membrane filters prewashed with $500 \mathrm{~mL}$ of deionized water and rinsed with a few $\mathrm{mL}$ of the sample itself. Filtered water samples were acidified using $1 \mathrm{~N} \mathrm{HCl}\left(1 \mathrm{mLL}^{-1}\right.$ of sample) to remove inorganic carbon and were then frozen and freezedried.

\subsection{Analytical procedure}

We introduced approximately $2 \mathrm{mg}$ of solid residue (soil or lyophilizate) into an $80 \mu \mathrm{L}$ aluminum reactor with an excess of solid tetramethylammonium hydroxide (TMAH ca. $10 \mathrm{mg}$ ). The THM reaction was performed online using a vertical micro-furnace pyrolyser PZ-2020D (Frontier Laboratories, Japan) operating at $400{ }^{\circ} \mathrm{C}$ for $1 \mathrm{~min}$. The products of this reaction were injected into a gas chromatograph (GC) GC-2010 (Shimadzu, Japan) equipped with a SLB 5MS capillary column in the split mode $(60 \mathrm{~m} \times 0.25 \mathrm{~mm}$ ID, $0.25 \mu \mathrm{m}$ film thickness). The split ratio was adapted according to the sample and ranged from 15 to 30 . The temperature of the transfer line was $321^{\circ} \mathrm{C}$ and the temperature of the injection port was $310^{\circ} \mathrm{C}$. The oven was programmed to maintain an initial temperature of $50^{\circ} \mathrm{C}$ for $2 \mathrm{~min}$, then rise to $150^{\circ} \mathrm{C}$ at $15^{\circ} \mathrm{C} \mathrm{min}^{-1}$ and then rise to $310^{\circ} \mathrm{C}$ at $3{ }^{\circ} \mathrm{C} \mathrm{min}-1$, where it stayed for $14 \mathrm{~min}$. Helium was used as the carrier gas, with a flow rate of $1.0 \mathrm{~mL} \mathrm{~min}^{-1}$. Compounds were detected using a QP2010+ mass spectrometer (MS) (Shimadzu, Japan) operating in the full-scan mode. The temperature of the transfer line was set at $280^{\circ} \mathrm{C}$, the ionization source at $200^{\circ} \mathrm{C}$ and molecules were ionized by electron impact using an energy of $70 \mathrm{eV}$. The list of analyzed compounds and $\mathrm{m} / \mathrm{z}$ ratios used for their integration are given in the Supplement (Table S1 in Supplement). Compounds were identified on the basis of their full-scan mass spectra by comparison with the NIST library and with published data (Nierop et al., 2005; Nierop and Verstraten, 2004). They were classified into three categories: lignin and tannin (LIG-TAN) markers, carbohydrates (CAR) and fatty acids (FA). The peak area of the selected $\mathrm{m} / \mathrm{z}$ for each compound was integrated and corrected by a mass spectra factor (MSF) calculated as the reciprocal of the proportion of the fragment used for the integration and the entire fragmentogram provided by the NIST library. The proportion of each compound class was calculated by dividing the sum of the areas of the compounds in this class by the sum of the peak areas of all analyzed compounds expressed as a percentage. Since no internal standards were used, data were interpreted qualitatively. Five samples were analyzed in triplicate to quantify the reproducibility of the analysis. The relative standard deviation (RSD) calculated for carbohydrate proxy, lignin-tannin proxies and the proportion of plant-derived markers was 9,10 and $6 \%$, respectively. The uncertainties given in Figs. 3, 4, 5 and S1 correspond to these mean RSD values. The use of THM-GC-MS to investigate the temporal variability in the DOM composition meant that it was necessary to assume that the ionization efficiency and matrix effects are equivalent for all analyzed compounds in all samples.

\subsection{Analysis of molecular data}

We used two metrics to investigate the distribution of lignintannin markers produced by the THM reaction. First, we used the ratio of the sum of coumaric and ferulic acid to the sum of vanillic acid, vanillaldehyde and acetovanillone (C / V ratio). Second, we used the ratio of vanillic acid to vanillaldehyde ( $\mathrm{Ac} / \mathrm{Al}(\mathrm{V})$ ratio).

We classified molecular markers generated by THM-GCMS into microbial and plant-derived markers as described by Jeanneau et al. (2014). Briefly, lignin-tannins were characteristic of DOM derived from plant sources, whereas carbohydrates and fatty acids can come from both plant and microbial sources. The proportion of microbial carbohydrates was calculated using an end-member mixing approach (EMMA; 


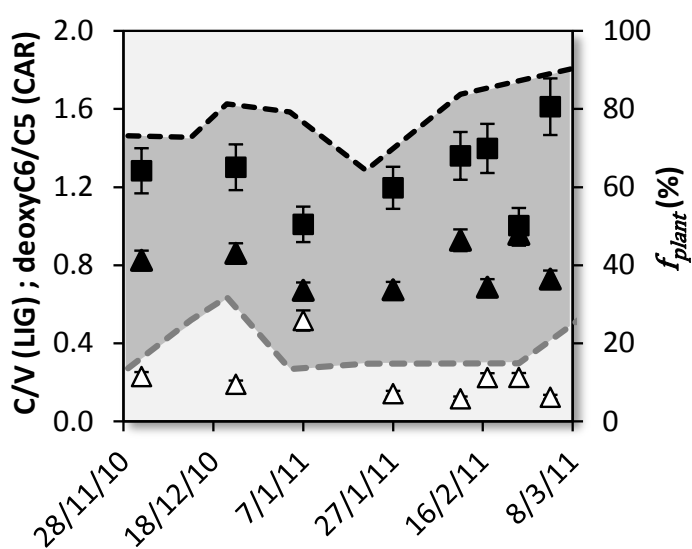

Caption:

Inter-storm stream DOM

- deoxyC6/C5

$\triangle \quad C / V$

$\Delta f_{\text {plant }}$

Soil DOM: $f_{\text {plant }}$

- - - Organo-mineral horizon

-- - Mineral horizon

Figure 3. Variation in the molecular composition of inter-storm DOM in the stream $\left(\mathrm{C} / \mathrm{V}\right.$, deoxyC6 / C5 and $\left.f_{\text {plant }}\right)$. The grey area is delimited by the $f_{\text {plant }}$ in soil DOM from the organomineral and mineral horizons. Dates are given in day/month/year.

Eq. 1) based on the deoxyC6/ $\mathrm{C} 5$ ratio, assuming 0.5 and 2.0 for plant-derived (deoxyC6 / $5_{\text {plant }}$ ) and microbial (deoxyC6 $/ \mathrm{C}_{\mathrm{mic}}$ ) inputs, respectively (Rumpel and Dignac, 2006):

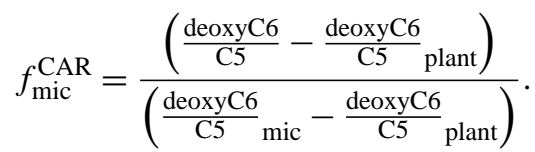

C6 were not considered since they can derive from the THM of cellulose, leading to an increase in the plant-derived C6 signal. The proportion of microbial fatty acids was calculated as the percentage of low molecular weight fatty acids ( $<$ C19) by excluding C16:0 and C18:0, which can be derived from plant or microbial inputs. The microbial FA were composed of C12:0, C13:0, C14:0, C15:0, C17:0, anteiso and iso $\mathrm{C} 15: 0$ and $\mathrm{C} 17$ : 0, iso $\mathrm{C} 16: 0, \mathrm{C} 16: 1$, and C18: 1, which are commonly used as bacterial indicators (Frostegård et al., 1993). The fraction of microbial markers $\left(f_{\text {mic }}\right)$ was calculated as the sum of the proportion of microbial CAR $\left(f_{\text {mic }}^{\mathrm{CAR}}\right)$ multiplied by the proportion of CAR $\left(\%_{\mathrm{CAR}}\right)$ plus the proportion of microbial FA $\left(f_{\text {mic }}^{F A}\right)$ multiplied by the proportion of FA (\%FA) (Eq. 2):

$f_{\text {mic }}=f_{\text {mic }}^{\mathrm{CAR}} \times \%_{\mathrm{CAR}}+f_{\text {mic }}^{\mathrm{FA}} \times \%_{\mathrm{FA}}$.

From this value, it is possible to calculate the proportion of plant-derived markers among the analyzed compounds $\left(f_{\text {plant }}\right)$ (Eq. 3):

$f_{\text {mic }}+f_{\text {plant }}=100$.

For these calculations, we assume that the distribution of carbohydrates and fatty acids was conserved during transport, attributing all differences to the relative proportion of plantderived and microbial inputs. Although these assumptions still need to be validated by investigating pure and known mixtures of vegetal and microbial sources, this approach can be used to approximate $f_{\text {mic }}$ and $f_{\text {plant }}$.

\section{Results}

\subsection{Soils and soil solution}

Ratios of lignin-tannin composition were poorly associated with spatiotemporal variations in the composition of soil DOM in the Mercy Wetland (Jeanneau et al., 2014). However, the ratios can differentiate between stream DOM and inter-storm and from storm conditions (Dalzell et al., 2005; Hernes et al., 2008), leading to the assumption of stream DOM produced by an erosive process. In SOM from the Mercy Wetland, the C / V ratio was 1.3 and 1.6 in surface and deep horizons, respectively. The $\mathrm{Ac} / \mathrm{Al}(\mathrm{V})$ ratio was 2.6 and 1.6 in surface and deep horizons, respectively. In soil DOM from 29 November 2010 to 11 March 2011, the C / V ratio ranged from 0.2 to 0.4 in the surface horizon and remained stable at 0.2 in the deep horizon. The $\mathrm{Ac} / \mathrm{Al}(\mathrm{V})$ ratio ranged from 7.1 to $12.1(9.1 \pm 1.7$, mean $\pm \mathrm{SD})$ in the surface horizon and from 3.6 to $6.9(4.7 \pm 1.2$, mean $\pm \mathrm{SD})$ in the deep horizon.

\subsection{River DOM in inter-storm conditions}

In river samples from 28 November 2010 to 8 March 2011, $f_{\text {plant }}$ ranged from 34 to $48 \%$ of all analyzed compounds (Fig. 3). Among carbohydrates, the ratio deoxyC6/C5 ranged from 1.0 to 1.6 , and heptoses have never been detected in those samples. For lignin-tannin, the $\mathrm{C} / \mathrm{V}$ ratio remained lower than 0.2 , with the exception of the sampling of 7 January 2011, which had a value of 0.5. The Ac / Al (V) ratio ranged from 4.5 to 7.7 .

\subsection{River DOM during storm events}

During the five sampled storm events, the DOM composition showed shifts in isotopes (Lambert et al., 2014) and molecular markers analyses (Figs. 4 and S1 in Supplement, Table 1). The modifications, displayed in Fig. 4 for the events 3 and 4 , were relatively consistent for the five storm events. During storm events, $f_{\text {plant }}$ increased from an initial value of 31 (events 2, 4 and 6), 49 (event 3) and $14 \%$ (event 5), reaching maximal values of $63 \%$ (event 6 ) to $82 \%$ (event 3 ) during peak flow (Fig. 4 and Table 1). After the peak flow, $f_{\text {plant }}$ decreased by approximately $10 \%$ (events $2,4,5$ and 6 ) or 
Event 3: 19/12/2010
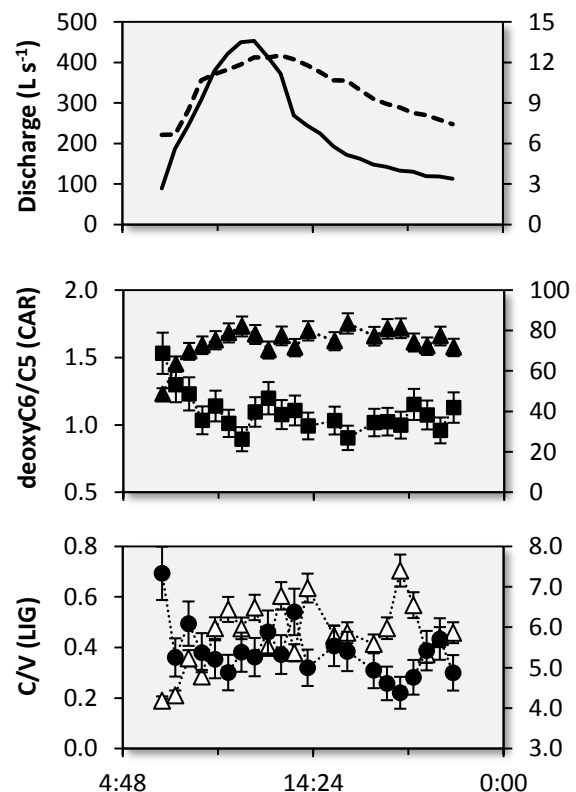

Event 4: 06/01/2011

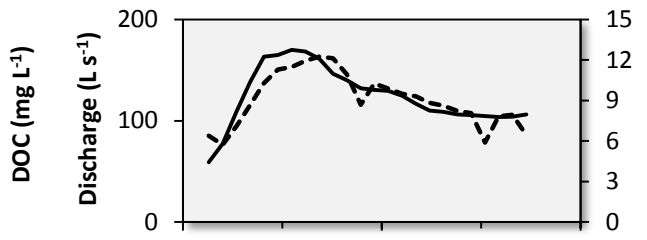

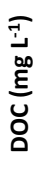
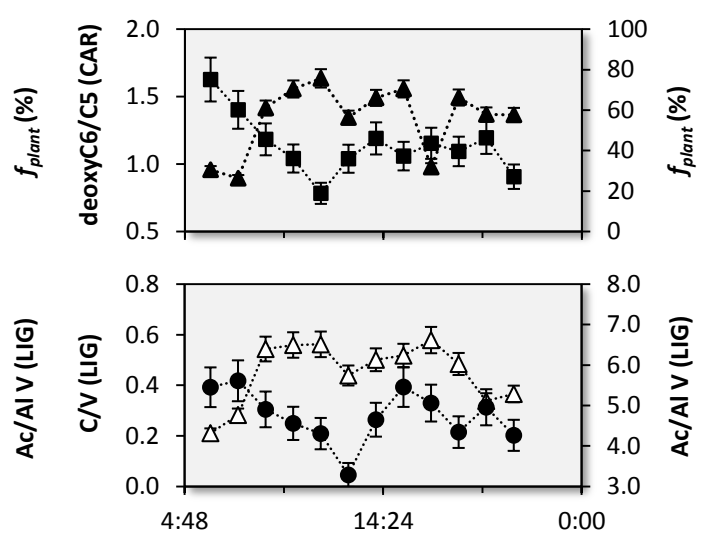

Caption:

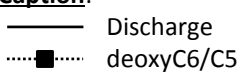

$\begin{array}{ll}--- & {[D O C]} \\ \cdots \cdots & C / V\end{array}$

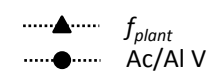

Figure 4. Temporal change in flow and DOC concentration and composition during storm events 3 and 4 . Various units indicated in the axis labels. The uncertainties for deoxyC6 / C5, $f_{\text {plant }}, \mathrm{C} / \mathrm{V}$ and $\mathrm{Ac} / \mathrm{Al}(\mathrm{V})$ are the mean RSDs calculated for five samples analyzed in triplicate.

Table 1. Changes in discharge, DOC concentration and metrics of DOM composition during storm events. Values are given for the first, peak discharge, and final samples.

\begin{tabular}{llrrcccc}
\hline Date (Event) & & $\begin{array}{r}\text { Discharge } \\
\left(\mathrm{L} \mathrm{s}^{-1}\right)\end{array}$ & $\begin{array}{r}\text { DOC } \\
\left(\mathrm{mg} \mathrm{L}^{-1}\right)\end{array}$ & $\begin{array}{c}f_{\text {plant }} \\
(\%)\end{array}$ & deoxyC6/C5 & C / V & Ac / Al (V) \\
\hline 4 Dec 2010 (2) & beg. $^{\mathrm{a}}$ & 79.8 & 7.4 & 31 & 1.6 & 0.2 & 5.0 \\
& max. $^{\mathrm{b}}$ & 177.3 & 11.6 & 67 & 0.9 & 0.4 & 5.2 \\
& end & 127.4 & 9.8 & 57 & 1.1 & 0.5 & 4.7 \\
\hline 19 Dec 2010 (3) & beg. $^{\mathrm{a}}$ & 88.8 & 6.6 & 49 & 1.5 & 0.2 & 7.3 \\
& max. $^{\mathrm{b}}$ & 453.1 & 12.4 & 78 & 1.1 & 0.6 & 5.3 \\
& end & 113.1 & 7.4 & 72 & 1.1 & 0.5 & 4.9 \\
\hline \multirow{2}{*}{ 6 Jan 2011 (4) } & beg. $^{\mathrm{a}}$ & 59.1 & 6.4 & 31 & 1.6 & 0.2 & 5.5 \\
& max. $^{\mathrm{b}}$ & 169.8 & 11.5 & 70 & 1.0 & 0.6 & 4.6 \\
& end & 104.0 & 8.0 & 58 & 0.9 & 0.4 & 4.3 \\
\hline 13 Feb 2011 (5) & beg. $^{\mathrm{a}}$ & 72.8 & 7.4 & 14 & 2.7 & 0.2 & 6.6 \\
& max. $^{\mathrm{b}}$ & 167.3 & 12.8 & 71 & 1.1 & 0.4 & 5.5 \\
& end & 96.2 & 11 & 60 & 1.2 & 0.4 & 4.8 \\
\hline 19 Feb 2011 (6) & beg. $^{\mathrm{a}}$ & 77.7 & 8 & 31 & 1.9 & 0.3 & 5.2 \\
& max. & 245.1 & 15.5 & 59 & 1.3 & 0.8 & 4.5 \\
& end & 102.5 & 9.1 & 25 & 1.4 & 0.3 & 4.6 \\
\hline
\end{tabular}

${ }^{a}$ Value recorded at the beginning of storm events. ${ }^{b}$ Value recorded at the peak discharge. 
remained stable (event 3) until the end of the sample collection.

Composition of carbohydrate, as reflected in the deoxyC6 / C5 ratio, also varied during storm events, decreasing with discharge from initial values ranging from 1.5 to 2.7 , reaching its minimal value at peak flow and then remaining stable through the end of the sampling. Heptoses were detected in the first samples at the beginning of all storm events and up to the fifth sample for event 2 (Fig. S2).

The $\mathrm{C} / \mathrm{V}$ and $\mathrm{Ac} / \mathrm{Al}(\mathrm{V})$ ratios, metrics of the composition of lignin-tannin, were modified during storm events. The C / V ratio increased with discharge from 0.2 at the beginning of storm events to 0.5 (event 5), 0.6 (events 2 and 4), 0.7 (event 3 ) and 0.8 (event 6). Depending of the storm event, this value slightly decreased or remained stable through the end of the sampling. The evolution of the $\mathrm{Ac} / \mathrm{Al}(\mathrm{V})$ ratio was storm-dependant. For events 2, 4 and 6, it remained stable around 5.0 with a few extreme values, while for events 3 and 5, it decreased from 7.0 to 5.0 with the increase in discharge and then remained stable through the end of the sampling.

\section{Discussion}

\subsection{Inter-storm stream DOM}

The $f_{\text {plant }}$ of inter-storm stream DOM was composed of a mix of soil DOM from the organic-rich and organic-poor horizons (Fig. 3). Since $f_{\text {plant }}$ of soil DOM differed strongly between organomineral and mineral horizons and was fairly stable during the investigated period (Fig. 3), it can be used in an end member mixing approach to determine the relative DOM contributions of organomineral and mineral horizons. From 29 November 2010 to 11 March 2011, the proportion of stream DOM originating from organomineral horizon ranged from 23 to $59 \%$ ( $37 \pm 13 \%$, mean $\pm \mathrm{SE})$. This confirms previous findings that near-surface, organic-rich soils in riparian wetland zones are important DOM sources during non-storm conditions (Strohmeier et al., 2013).

\subsection{A pulse of microbial DOM at the beginning of storms}

At the beginning of the storm events $f_{\text {plant }}$ of stream DOM decreased, except in the case of event 3 . The higher value recorded for event 3 was likely due to an increase in discharge the previous day (from 48 to $78 \mathrm{~L} \mathrm{~s}^{-1}$; Table S2), which could have mobilized microbial compounds before the first sampling. Stream DOM at the beginning of storm events was also characterized by higher deoxyC6/C5 ratio than during inter-storm conditions and by the occurrence of heptoses. Heptoses have been detected in microbial exopolysaccharides (Jiao et al., 2010) and lipopolysaccharides (Sadovskaya et al., 1998). The export of microbial DOM, evidenced by the presence of heptoses and high $f_{\text {mic }}$, was most prevalent for event 5 , where $86 \%$ of the analyzed biomarkers were of microbial origin during the earliest stages of the storm. This was the first flood after the onset of reducing conditions in wetland soils (Lambert et al., 2013), when the riparian wetland zones at the soil-river interface were a hot spot of iron reduction.

This pool of microbial DOM could be derived from a flushing of microbial lysis products accumulated in soils over the dry period (Christ and David, 1996). However, the five sampled storm events occurred during the hydrological phase B, where riparian wetland soils are continuously waterlogged, precluding the possibility of lysis from desiccation. Moreover, heptoses were not detected in soil DOM or in stream DOM samples during inter-storm conditions. Alternatively, microbially derived DOM could come from microbial biofilms in soil macropores or at the wetland-stream interface (Knorr, 2013) that are destabilized and transported into the stream by the increase in water velocity at the beginning of storm events (Trulear and Characklis, 1982). Regardless of the mechanism, this pulse of microbial DOM at the beginning of storm events could account for the compositional shift in stream DOM observed with high-frequency fluorescence measurements and displayed in the literature. Indeed, soil DOM of the first storm samples is often characterized by high proportions of protein-like chromophores, low proportions of humic-like chromophores (Knorr, 2013), a high fluorescence index and low SUVA (Inamdar et al., 2011; Vidon et al., 2008).

\subsection{Soil erosion as a DOM producer}

Storm events caused a shift in the compositional ratios of lignin-tannin. The $\mathrm{C} / \mathrm{V}$ ratio increased from 0.2 to 0.8 and the $\mathrm{Ac} / \mathrm{Al}(\mathrm{V})$ ratio decreased from 7 to 5, except in the case of event 6 , where it remained stable around 5. These modifications of lignin-tannin transfer from soils to rivers during flood events are in accordance with data on lignin phenols obtained along the Big Pine Creek watershed (Dalzell et al., 2005) and the Willow Slough watershed (Hernes et al., 2008). In both of those watersheds, stream DOM during storms was characterized by higher $\mathrm{C} / \mathrm{V}$ and lower $\mathrm{Ac} / \mathrm{Al}$ (V) ratios than DOM sampled during inter-storm conditions. Although the differences in analytical techniques makes a direct data comparison difficult (Wysocki et al., 2008), the compositional ratios show the same pattern during biodegradation with a decrease in the $\mathrm{C} / \mathrm{V}$ ratio and an increase in the $\mathrm{Ac} / \mathrm{Al}$ (V) ratio (Kabuyah et al., 2012; Vane et al., 2005). The aforementioned modifications of $\mathrm{C} / \mathrm{V}$ and $\mathrm{Ac} / \mathrm{Al}(\mathrm{V})$ ratios have consequently been attributed to the mobilization of less degraded lignins during flood events (Dalzell et al., 2005; Hernes et al., 2008).

In soils, the separation of $\mathrm{OM}$ into the particulate phase (SOM) and the soil solution (soil DOM) occurs continuously with a high soil / water ratio producing soil DOM characterized by low C / V (around 0.2). During a storm events, the 

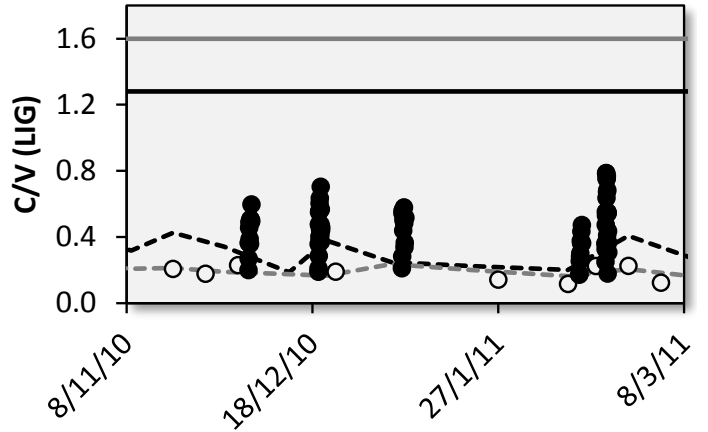

Caption:

SOM: — OM layer; - M layer

Soil DOM: --- OM layer; --- M layer

Stream DOM: O inter-storm; $\bullet$ storm

Figure 5. Variation in the $\mathrm{C} / \mathrm{V}$ ratio (lignin proxy) in SOM, soil DOM from organomineral and mineral horizons, and stream DOM sampled during inter-storm and storm conditions. Dates are given in day/month/year.

values of the $\mathrm{C} / \mathrm{V}$ ratio in stream DOM increased to values higher than those recorded in the soil solutions. Thus, stream DOM during storms cannot only result from the passive transfer of preexisting soil DOM to the stream. Of all the known DOM sources in the catchment, only SOM has $\mathrm{C} / \mathrm{V}$ values that could explain the elevated storm DOM values (Fig. 5). In the Willow Slough catchment, the concentration in lignin markers is correlated with the concentration of suspended matter, indicating that a portion of DOM during storm events can be inherited from the separation of organic compounds into solid and dissolved phases (Hernes et al., 2008). Lignin-tannin and suspended sediment were also correlated in the present study, as seen in the regression between turbidity and C / V ratio (Fig. 6). During storm event, erosion carries particles in water. These conditions characterized by low soil / water ratios could induce a displacement of the equilibrium between $\mathrm{OM}$ in the solid phase and $\mathrm{OM}$ in the dissolved phase, which would lead to DOM with a high C / V (higher or equal to 0.8 ). Soil erosion and the equilibrium between solid (soil particles) and dissolved (river) phases is likely an additional source of DOM transfer from soil to rivers during storm events.

However, the positive relationship between turbidity and $\mathrm{C} / \mathrm{V}$ ratio occurs primarily during the rising limb of the hydrograph (grey diamond, Fig. 6; $R^{2}=0.68, p$ value $<0.0001, n=23$ ), whereas after peak discharge, turbidity decreased while the $\mathrm{C} / \mathrm{V}$ ratio remained high, leading to a weaker correlation when all the samples are considered (black diamond, Fig. 6; $R^{2}=0.11, p$ value $=0.008, n=64$ ). The persistence of high $\mathrm{C} / \mathrm{V}$ ratios during the falling limb of the hydrograph highlights how other DOM production mechanisms inducing conditions characterized by low soil/water ratios are also active are also active during storms in addi-

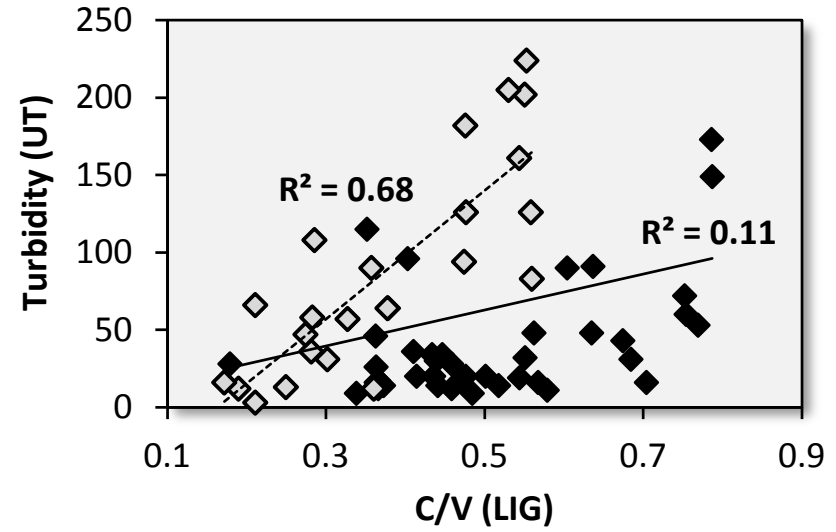

Caption:

$\diamond$ Rising limb $\diamond$ Entire event

Figure 6. Correlation between turbidity and the $\mathrm{C} / \mathrm{V}$ ratio (lignin proxy) during the rising limbs (grey diamonds $-p$ value $<0.0001$ ) and during entire storm events (black diamonds $-p$ value $=0.008$ ).

tion to soil erosion. This could come from the exposure of new surfaces within soil structures, following destabilization and the disaggregation of soil aggregates during the erosion of macropores walls during storm flow (Wilson et al., 2005). Such a mechanism could modify DOM production in soil profiles, causing a shift in DOM composition persisting past peak flow, without adding suspended solids to the stream, the latter particles being physically trapped by the soil matrix.

\subsection{Temporal scheme of DOM-producing processes during storm events}

Divergent behavior in the response of DOM concentration and composition to storms as we observed here has been documented in other catchments in various climates, with modifications to DOM composition typically persisting after concentration has returned to pre-event levels (Austnes et al., 2010; Knorr, 2013; Singh et al., 2015). This suggests that the mechanisms controlling DOM transport during different hydrologic conditions are general. Our work, in combination with previous results, suggests a succession of four distinct mechanisms. First, between storms, DOM comes from the flushing of wetland soils horizons without major compositional changes in DOM during transport. The water table level would determine the contribution of organomineral and mineral soil horizons during this period. Second, at the beginning of rain events, the increase in water velocity could induce the destabilization of microbial biofilms, resulting in the release of a pulse of microbially derived DOM. Third, the rise in the water table, in association with the decrease in lateral hydraulic conductivity with depth (Seibert et al., 2009) would increase the proportion of the water flowing through the upper, organic-rich surface horizon in the wetland, causing an increase in the stream DOC concentration. At the same 
time, erosion of soils and riverbanks would increase turbidity, leading to a partition of organic matter between particulate and dissolved phases. The magnitude of the effect of this soil surface erosive process on DOM chemistry would depend on the concentration of suspended matter and would therefore decrease during the falling limb of the hydrograph. Finally, the increase in water velocity in soils could erode macropore walls in the soil profile, leading to an in-soil partition between soil microparticles and dissolved phase. The contribution of this in-soil erosive process would be linked to the magnitude of the hydraulic gradient following the rise of the water table. Since the return to pre-event conditions takes longer in the soil profile than for discharge (Lambert et al., 2014 - Fig. 3b), this could explain why compositional proxies of DOM do not recover as quickly as stream DOC concentrations. High-frequency sampling of soil solutions during and after storm events until a return to pre-event values would be necessary to test these proposed mechanisms.

\section{Summary and implications}

We observed striking changes in DOM sources and transfer processes during and between storm events. While DOM during inter-storm conditions appears to be derived from the passive transfer of DOM from riparian wetland soils, during storm periods the DOM transferred from soil to the stream was not only due to the flushing of DOM already present in soils but also to additional sources and production processes that increase the proportion of less degraded molecules in the dissolved phase. Based on the current literature, these findings appear to quite general features of DOM transfer in lowland catchments worldwide and have two important implications.

First, these results enhance our understanding of the transfer of micropollutants, which is largely controlled by the complex properties of OM. The leaching of DOM from SOM during storm events increased the prevalence of less biodegraded but more hydrophobic molecules (Kleber and Johnson, 2010). SOM hydrophobicity is believed to be the main driving force of the retention of hydrophobic micropollutants in soils, such as many pesticides and antibiotics ( $\mathrm{Ji}$ et al., 2011). Increases in less biodegraded, hydrophobic DOM during storms could therefore lead to an enhanced transfer of these harmful compounds from soils to streams, increasing their bioavailability and consequently their undesirable effects, such as antibiotic resistance (Hellweger et al., 2011).

Secondly, our work has implications for modeling DOM export in headwater catchments. In lowland headwater catchments, up to $80 \%$ of DOM is transferred during storm events (Raymond and Saiers, 2010), and many modeling studies assume that DOM transfer during storm events consists of the flushing of preexisting soil pools. Since these soil DOM pools are calibrated for concentration and composition using samples taken in inter-storm conditions, these mod- els do not account for alternative DOM-producing processes activated during storms, such as the surface and subsurface erosion processes proposed here. This oversight could explain why modeling studies succeed in reproducing interstorm DOM concentrations but not storm flow DOM dynamics (Birkel et al., 2014). Increased interaction between geochemists and modelers could accelerate the conceptualization of temporally and spatially variant DOM production mechanisms and improve the modeling of DOM export.

\section{The Supplement related to this article is available online at doi:10.5194/bg-12-4333-2015-supplement.}

Acknowledgements. We thank the technical staff from INRA and Géosciences Rennes for their assistance during the fieldwork. This research was funded by the University of Rennes 1 through the "Varia-MOD" project and by the CNRS through the EC2CO "Prodynamos" project. We used data provided online by the environmental observatory ORE AgrHys (www6.inra.fr/ore_agrhys_eng/). The authors thank B. W. Abbott, who copy-edited the manuscript.

Edited by: C. Woulds

\section{References}

Ågren, A., Buffam, I., Jansson, M., and Laudon, H.: Importance of seasonality and small streams for the landscape regulation of dissolved organic carbon export, J. Geophys. Res.-Biogeosci., 112, G03003, doi:10.1029/2006JG000381, 2007.

Aubert, A. H., Gascuel-Odoux, C., Gruau, G., Akkal, N., Faucheux, M., Fauvel, Y., Grimaldi, C., Hamon, Y., Jaffrézic, A., Lecoz-Boutnik, M., Molénat, J., Petitjean, P., Ruiz, L., and Merot, P.: Solute transport dynamics in small, shallow groundwater-dominated agricultural catchments: insights from a high-frequency, multisolute $10 \mathrm{yr}$-long monitoring study, Hydrol Earth Syst. Sci., 17, 1379-1391, 2013, http://www.hydrol-earth-syst-sci.net/17/1379/2013/.

Austnes, K., Evans, C., Eliot-Laize, C., Naden, P., and Old, G.: Effects of storm events on mobilisation and in-stream processing of dissolved organic matter (DOM) in a Welsh peatland catchment, Biogeochemistry, 99, 157-173, 2010.

Billett, M. F., Deacon, C. M., Palmer, S. M., Dawson, J. J. C., and Hope, D.: Connecting organic carbon in stream water and soils in a peatland catchment, J. Geophys. Res.-Biogeosci., 111, G02010, doi:10.1029/2005JG000065, 2006.

Birkel, C., Soulsby, C., and Tetzlaff, D.: Integrating parsimonious models of hydrological connectivity and soil biogeochemistry to simulate stream DOC dynamics, J. Geophys. Res.-Biogeosci., 119, 2013JG002551, doi:10.1002/2013JG002551, 2014.

Bishop, K., Buffam, I., Erlandsson, M., Fölster, J., Laudon, H., Seibert, J., and Temnerud, J.: Aqua Incognita: the unknown headwaters, Hydrol. Process., 22, 1239-1242, 2008. 
Christ, M. J. and David, M. B.: Temperature and moisture effects on the production of dissolved organic carbon in a Spodosol, Soil Biol. Biochem., 28, 1191-1199, 1996.

Cole, J. J., Prairie, Y. T., Caraco, N. F., McDowell, W. H., Tranvik, L. J., Striegl, R. G., Duarte, C. M., Kortelainen, P., Downing, J. A., Middelburg, J. J., and Melack, J.: Plumbing the Global Carbon Cycle: Integrating Inland Waters into the Terrestrial Carbon Budget, Ecosystems, 10, 172-185, 2007.

Corapcioglu, M. Y. and Jiang, S.: Colloid-facilitated groundwater contaminant transport, Water Resour. Res., 29, 2215-2226, 1993.

Cranwell, P. A.: Monocarboxylic acids in lake sediments: Indicators, derived from terrestrial and aquatic biota, of paleoenvironmental trophic levels, Chem. Geol., 14, 1-14, 1974.

Crave, A. and Gascuel-Odoux, C.: The influence of topography on time and space distribution of soil surface water content, Hydrol. Process., 11, 203-210, 1997.

Dalzell, B. J., Filley, T. R., and Harbor, J. M.: Flood pulse influences on terrestrial organic matter export from an agricultural watershed, J. Geophys. Res., 110, G02011, doi:10.1029/2005JG000043, 2005.

Durand, P. and Juan Torres, J. L.: Solute transfer in agricultural catchments: the interest and limits of mixing models, J. Hydrol., 181, 1-22, 1996.

Eglinton, G. and Hamilton, R. J.: Leaf epicuticular waxes, Science, 156, 1322-1335, 1967.

Frostegård, A., Tunlid, A., and Bååth, E.: Phospholipid Fatty Acid Composition, Biomass, and Activity of Microbial Communities from Two Soil Types Experimentally Exposed to Different Heavy Metals, Appl. Environ. Microbiol., 59, 3605-3617, 1993.

Grasset, L., Rovira, P., and Amblès, A.: TMAH-preparative thermochemolysis for the characterization of organic matter in densimetric fractions of a Mediterranean forest soil, J. Anal. Appl. Pyrolysis, 85, 435-441, 2009.

Hedges, J. I. and Parker, P. L.: Land-derived organic matter in surface sediments from the Gulf of Mexico, Geochim. Cosmochim. Acta, 40, 1019-1029, 1976.

Hellweger, F. L., Ruan, X., and Sanchez, S.: A Simple Model of Tetracycline Antibiotic Resistance in the Aquatic Environment (with Application to the Poudre River), Int. J. Environ. Res. Public. Health, 8, 480-497, 2011.

Hernes, P. J., Spencer, R. G. M., Dyda, R. Y., Pellerin, B. A., Bachand, P. A. M., and Bergamaschi, B. A.: The role of hydrologic regimes on dissolved organic carbon composition in an agricultural watershed, Geochim. Cosmochim. Acta, 72, 5266-5277, 2008.

Hinton, M. J., Schiff, S. L., and English, M. C.: Sources and flowpaths of dissolved organic carbon during storms in two forested watersheds of the Precambrian Shield, Biogeochemistry, 41, 175-197, 1998.

Hood, E., Gooseff, M. N., and Johnson, S. L.: Changes in the character of stream water dissolved organic carbon during flushing in three small watersheds, Oregon, J. Geophys. Res., 111, G01007, doi:10.1029/2005JG000082, 2006.

Inamdar, S., Singh, S., Dutta, S., Levia, D., Mitchell, M., Scott, D., Bais, H., and McHale, P.: Fluorescence characteristics and sources of dissolved organic matter for stream water during storm events in a forested mid-Atlantic watershed, J. Geophys. Res., 116, G03043, doi:10.1029/2011JG001735, 2011.
IUSS Working Group WRB: World reference base for soil resources 2006, World Soil Resources Reports No. 103. FAO, Rome, 2006.

Jeanneau, L., Jaffrezic, A., Pierson-Wickmann, A.-C., Gruau, G., Lambert, T., and Petitjean, P.: Constraints on the Sources and Production Mechanisms of Dissolved Organic Matter in Soils from Molecular Biomarkers, Vadose Zone J., 13, 2014.

Ji, L., Wan, Y., Zheng, S., and Zhu, D.: Adsorption of Tetracycline and Sulfamethoxazole on Crop Residue-Derived Ashes: Implication for the Relative Importance of Black Carbon to Soil Sorption, Environ. Sci. Technol., 45, 5580-5586, 2011.

Jiao, Y., Cody, G. D., Harding, A. K., Wilmes, P., Schrenk, M., Wheeler, K. E., Banfield, J. F., and Thelen, M. P.: Characterization of Extracellular Polymeric Substances from Acidophilic Microbial Biofilms, Appl. Environ. Microbiol., 76, 2916-2922, 2010.

Kabuyah, R. N. T. M., van Dongen, B. E., Bewsher, A. D., and Robinson, C. H.: Decomposition of lignin in wheat straw in a sand-dune grassland, Soil Biol. Biochem., 45, 128-131, 2012.

Kicklighter, D. W., Hayes, D. J., McClelland, J. W., Peterson, B. J., McGuire, A. D., and Melillo, J. M.: Insights and issues with simulating terrestrial DOC loading of Arctic river networks, Ecol. Appl., 23, 1817-1836, 2013.

Kleber, M. and Johnson, M. G.: Advances in Understanding the Molecular Structure of Soil Organic Matter: Implications for Interactions in the Environment, Adv. Agr., 106, 77-142, 2010.

Knorr, K.-H.: DOC-dynamics in a small headwater catchment as driven by redox fluctuations and hydrological flow paths - are DOC exports mediated by iron reduction/oxidation cycles?, Biogeosciences, 10, 891-904, doi:10.5194/bg-10-891-2013, 2013.

Lambert, T., Pierson-Wickmann, A.-C., Gruau, G., Thibault, J.-N., and Jaffrezic, A.: Carbon isotopes as tracers of dissolved organic carbon sources and water pathways in headwater catchments, J. Hydrol., 402, 228-238, 2011.

Lambert, T., Pierson-Wickmann, A.-C., Gruau, G., Jaffrezic, A., Petitjean, P., Thibault, J.-N., and Jeanneau, L.: Hydrologically driven seasonal changes in the sources and production mechanisms of dissolved organic carbon in a small lowland catchment, Water Resour. Res., 49, 1-12, 2013.

Lambert, T., Pierson-Wickmann, A.-C., Gruau, G., Jaffrezic, A., Petitjean, P., Thibault, J. N., and Jeanneau, L.: DOC sources and DOC transport pathways in a small headwater catchment as revealed by carbon isotope fluctuation during storm events, Biogeosciences, 11, 3043-3056, doi:10.5194/bg-11-3043-2014, 2014.

Lucas García, J. A., Barbas, C., Probanza, A., Barrientos, M. L., and Gutierrez Mañero, F. J.: Low molecular weight organic acids and fatty acids in root exudates of two Lupinus cultivars at flowering and fruiting stages, Phytochem. Anal., 12, 305-311, 2001.

Matsuda, H. and Koyama, T.: Early diagenesis of fatty acids in lacustrine sediments - II. A statistical approach to changes in fatty acid composition from recent sediments and some source materials, Geochim. Cosmochim. Acta, 41, 1825-1834, 1977.

Maurice, P. A., Cabaniss, S. E., Drummond, J., and Ito, E.: Hydrogeochemical controls on the variations in chemical characteristics of natural organic matter at a small freshwater wetland, Chem. Geol., 187, 59-77, 2002.

McDonnell, J. J.: Where does water go when it rains?, Moving beyond the variable source area concept of rainfall-runoff response, Hydrol. Process., 17, 1869-1875, 2003. 
McGlynn, B. L. and McDonnell, J. J.: Role of discrete landscape units in controlling catchment dissolved organic carbon dynamics, Water Resour. Res., 39, 1090, doi:10.1029/2002WR001525, 2003.

McLaughlin, C. and Kaplan, L. A.: Biological lability of dissolved organic carbon in stream water and contributing terrestrial sources, Freshw. Sci., 32, 1219-1230, 2013.

Molenat, J., Gascuel-Odoux, C., Ruiz, L., and Gruau, G.: Role of water table dynamics on stream nitrate export and concentration in agricultural headwater catchment (France), J. Hydrol., 348, 363-378, 2008.

Morel, B., Durand, P., Jaffrezic, A., Gruau, G., and Molenat, J.: Sources of dissolved organic carbon during stormflow in a headwater agricultural catchment, Hydrol. Process., 23, 2888-2901, 2009.

Nierop, K. G. J. and Verstraten, J. M.: Rapid molecular assessment of the bioturbation extent in sandy soil horizons under pine using ester-bound lipids by on-line thermally assisted hydrolysis and methylation-gas chromatography/mass spectrometry, Rapid Commun. Mass Spectrom., 18, 1081-1088, 2004.

Nierop, K. G. J., Preston, C. M., and Kaal, J.: Thermally Assisted Hydrolysis and Methylation of Purified Tannins from Plants, Anal. Chem., 77, 5604-5614, 2005.

Raymond, P. and Saiers, J.: Event controlled DOC export from forested watersheds, Biogeochemistry, 100, 197-209, 2010.

Raymond, P. A., Hartmann, J., Lauerwald, R., Sobek, S., McDonald, C., Hoover, M., Butman, D., Striegl, R., Mayorga, E., Humborg, C., Kortelainen, P., Durr, H., Meybeck, M., Ciais, P., and Guth, P.: Global carbon dioxide emissions from inland waters, Nature, 503, 355-359, 2013.

Rumpel, C. and Dignac, M.-F.: Gas chromatographic analysis of monosaccharides in a forest soil profile: Analysis by gas chromatography after trifluoroacetic acid hydrolysis and reductionacetylation, Soil Biol. Biochem., 38, 1478-1481, 2006.

Sadovskaya, I., Brisson, J.-R., Lam, J. S., Richards, J. C., and Altman, E.: Structural elucidation of the lipopolysaccharide core regions of the wild-type strain PAO1 and O-chain-deficient mutant strains AK1401 and AK1012 from Pseudomonas aeruginosa serotype O5, Eur. J. Biochem., 255, 673-684, 1998.

Saraceno, J. F., Pellerin, B. A., Downing, B. D., Boss, E., Bachand, P. A. M., and Bergamaschi, B. A.: High-frequency in situ optical measurements during a storm event: Assessing relationships between dissolved organic matter, sediment concentrations, and hydrologic processes, J. Geophys. Res., 114, G00F09, doi:10.1029/2009JG000989, 2009.
Seibert, J., Grabs, T., Köhler, S., Laudon, H., Winterdahl, M., and Bishop, K.: Linking soil- and stream-water chemistry based on a Riparian Flow-Concentration Integration Model, Hydrol. Earth Syst. Sci., 13, 2287-2297, doi:10.5194/hess-13-22872009, 2009.

Singh, S., Inamdar, S., and Mitchell, M.: Changes in dissolved organic matter (DOM) amount and composition along nested headwater stream locations during baseflow and stormflow, Hydrol. Process., 29, 1505-1520, 2015.

Strohmeier, S., Knorr, K.-H., Reichert, M., Frei, S., Fleckenstein, J. H., Peiffer, S., and Matzner, E.: Concentrations and fluxes of dissolved organic carbon in runoff from a forested catchment: insights from high frequency measurements, Biogeosciences, 10, 905-916, doi:10.5194/bg-10-905-2013, 2013.

Trulear, M. G. and Characklis, W. G.: Dynamics of biofilm processes, J. Water Pollut. Control Fed., 54, 1288-1301, 1982.

Vane, C. H., Drage, T. C., Snape, C. E., Stephenson, M. H., and Foster, C.: Decay of cultivated apricot wood (Prunus armeniaca) by the ascomycete Hypocrea sulphurea, using solid state 13C NMR and off-line TMAH thermochemolysis with GC-MS, Int. Biodeterior. Biodegrad., 55, 175-185, 2005.

Vidon, P., Wagner, L., and Soyeux, E.: Changes in the character of DOC in streams during storms in two Midwestern watersheds with contrasting land uses, Biogeochemistry, 88, 257-270-270, 2008.

Wilson, G. V., Xu, M., Chen, Y., Liu, G., and Römkens, M. J. M.: Macropore flow and mass wasting of gullies in the Loess Plateau, China, Int. J. Sediment Res., 20, 249-258, 2005.

Wysocki, L. A., Filley, T. R., and Bianchi, T. S.: Comparison of two methods for the analysis of lignin in marine sediments: $\mathrm{CuO}$ oxidation versus tetramethylammonium hydroxide (TMAH) thermochemolysis, Org. Geochem., 39, 1454-1461, 2008.

Yang, L., Guo, W., Chen, N., Hong, H., Huang, J., Xu, J., and Huang, S.: Influence of a summer storm event on the flux and composition of dissolved organic matter in a subtropical river, China, Appl. Geochem., 28, 164-171, 2013. 